Jurnal InFestasi

Vol. 12, No.2, Desember 2016

Hal. $203-216$

\title{
MENINGKATKAN KEPATUHAN DAN PENERIMAAN PAJAK MELALUI WITHHOLDING TAX SYSTEM
}

\author{
I Nyoman Darmayasa ${ }^{1}$ \\ Yuyung Rizka Aneswari ${ }^{2}$ \\ Elana Era Yusdita ${ }^{3}$ \\ ${ }^{1}$ Politeknik Negeri Bali \\ ${ }^{2}$ STIE Kesuma Negara Blitar \\ 3Program Magister Akuntansi FEB Universitas Brawijaya \\ nyomandarmayasa@pnb.ac.id
}

\begin{abstract}
The research aimed to understand deeply about withholding tax system in Indonesia and propose taxation strategy to maximize withholding tax according to self assessment system. The research use interpretive paradigm with literature method approach. The result of the research indicate that first, tax compliance in Indonesia is still low category so it need efforts to improve. Second, with withholding tax system will assurance due tax payment because tax taker is more discipline to cut tax for tax payer. Third, withholding tax system can control effectively and efficiently to minimize examination object not for personal tax payer but for work or income giver. Fourth, through the withholding tax system, tax payers would cut taxes when the conditions of high economic capacity. Fifth, several proposals to improve the maximization WHT include expanding the tax base and direct tax cuts were not final is still possible into the final tax in the scheme of withholding tax, giving rewards to a third party who is disciplined and obedient, open access to the Direktorat Jenderal Pajak (DJP) on the banks of the effectiveness of tax policy and make the Single Identification Number (SIN) to attract new taxpayers. This study contributes to the formulation of policies Direktorat Jenderal Pajak (DJP).
\end{abstract}

\begin{abstract}
Abstrak
Penelitian ini bertujuan untuk memahami secara mendalam sistem pajak withholding di Indonesia yang selanjutnya mengajukan beberapa strategi perpajakan melalui maksimalisasi withholding tax yang tetap sejalan dengan Self Assessment System. Penelitian ini menggunakan paradigma interpretif dengan metode telaah literatur. Hasil penelitian menunjukkan bahwa pertama, kepatuhan pajak di Indonesia masih dalam kategori rendah dan perlu dilakukan upaya meningkatkan kepatuhan pajak. Kedua, melalui system withholding tax akan lebih menjamin kepastian pajak terbayar sebab yang memotong adalah pemberi penghasilan yang cenderung lebih disiplin. Ketiga, sistem withholding tax terbukti efektif dan efisien dalam pengawasan dengan mempersempit objek pemeriksaan bukan pada Wajib Pajak (WP) pribadi namun pada pemberi kerja atau pemberi penghasilan (pihak ketiga). Keempat, melalui sistem withholding tax, WP akan dipotong pajak ketika kondisi kemampuan ekonomi tinggi. Kelima, beberapa usulan untuk meningkatkan maksimalisasi WHT antara lain memperluas tax basis dan mengarahkan pemotongan pajak yang belum bersifat final yang masih memungkinkan ke dalam pajak yang bersifat final dalam skema withholding tax, memberikan reward pada pihak ketiga yang disiplin dan patuh, membuka akses Direktorat Jenderal Pajak (DJP) pada perbankan untuk keefektifan kebijakan perpajakan dan membuat Single Identification Number (SIN) untuk menjaring WP baru. Penelitian ini memberikan kontribusi pada penyusunan kebijakan-kebijakan DJP.
\end{abstract}

Kata kunci: Kepatuhan Pajak, Penerimaan Pajak, Self Assessment System (SAS), Tax Effort, Withholding Tax System 


\section{PENDAHULUAN}

Sistem Withholding Tax (WHT) yang diterapkan di Indonesia merupakan pembayaran pajak yang melibatkan pihak ketiga untuk pemotongan pajak. Sistem ini pertama kali diperkenalkan oleh Amerika Serikat untuk mempercepat penerimaan pajak selama Perang Dunia II (Rosdiana \& Irianto, 2014: 107-108). Penerimaan pajak tahun 2010 dan 2011 menunjukkan kontribusi WHT terhadap penerimaan pajak agregat patut diperhitungkan mencapai di atas 50\% (Pajak.go.id, 5/10/2012). Bahkan sampai dengan Mei 2015 ini, WHT dapat dikatakan menjadi penyelamat penerimaan pajak. $\mathrm{PPh}$ final dan $\mathrm{PPh}$ pasal 21 yang merupakan withholding tax sampai dengan akhir Mei 2015 tetap tinggi, apabila dibandingkan dengan periode yang sama tahun lalu mengalami pertumbuhan $21,48 \%$ dan $9,1 \%$ (Handoko, 26/06/2015).

Penelitian yang dilakukan oleh Andini \& Sumadi (2014) menjelaskan bahwa review pada pajak digunakan untuk melakukan pengecekan mengenai perhitungan pajak yang dilakukan oleh suatu perusahaan dan mengenai potensi pajak yang dapat digali dalam suatu perusahaan. Hasil penelitian Andini \& Sumadi (2014) yang mengambil objek penelitian pada hotel di Bali menunjukkan bahwa pelaporan WHT telah sesuai dengan ketentuan perpajakan.

Penelitian yang dilakukan oleh Ompusunggu (2009) membahas mengenai sinkronisasi penyempurnaan $\mathrm{PPh}$ pada pemotongan dan pemungutan WHT. Penelitian ini menyatakan bahwa tujuan WHT adalah untuk memfasilitasi atau mempercepat pengumpulan pajak, dengan mengumpulkan pajak dari pembayar pajak yang mana jumlahnya jauh lebih banyak dari pihak ketiga yang melakukan pemotongan pajak atau dalam penelitian ini disebut dengan party making a payment to another (PAYEE). Maka pemerintah memiliki tujuan untuk mengembangkan sistem administrasi
WHT melalui reformasi yang sesuai dengan UU No. 36 tahun 2008 tentang Pajak Penghasilan.

WHT merupakan kebijakan perpajakan yang sejalan dengan Self Assessment System (SAS). Beberapa penelitian telah dilakukan mengenai perilaku kepatuhan pajak di bawah SAS. Penelitian yang dilakukan oleh Palil \& Mustapha (2011) mengenai SAS di Malaysia menunjukkan bahwa untuk meningkatkan efektivitas SAS maka pemerintah perlu fokus pada cara memperluas pengetahuan pajak warga negara dan dengan cara seperti apa akan dapat berpengaruh pada kepatuhan pajak. Hal menarik dari penelitian Palil \& Mustapha (2011) adalah memberikan indikator pentingnya pengetahuan pajak sehingga perlu dimasukkan dalam desain program tax education dan melakukan simplifikasi sistem pajak. SAS juga merupakan salah satu kunci pendekatan administratif di negara maju seperti USA, UK dan Australia.

Penelitian yang dilakukan oleh Wahyuni (2011) dan Permita, Fauziati, Yulistia, \& Minovia (2014) justru menunjukkan hasil menarik mengenai SAS. Kedua penelitian ini dilakukan di Indonesia. Hasil penelitian keduanya menunjukkan bahwa SAS justru dapat membuka celah untuk dilakukan tax evasion atau penggelapan pajak.

Penelitian sebelumnya belum menggali lebih dalam mengenai potensi yang besar dari WHT dalam peran besarnya pada penerimaan pajak. Penelitian sebelumnya juga belum menjelaskan bahwa WHT bukan hanya efektif untuk mengumpulkan penerimaan pajak namun juga efisien. Sehingga penelitian ini bertujuan untuk menjelaskan secara mendalam sistem pajak withholding di Indonesia dan kemudian mengajukan beberapa strategi perpajakan dengan memaksimalkan withholding tax yang tetap inline dengan Self Assessment System (SAS) dalam upaya meningkatkan kepatuhan dan penerimaan pajak di Indonesia. Penelitian ini juga menggali bahwa 
melalui sistem WHT akan menutup celah terjadinya penggelapan pajak yang mungkin muncul dari SAS seperti hasil penelitian (Wahyuni, 2011) dan (Permita et al., 2014).

\section{METODE PENELITIAN}

Penelitian ini menggunakan paradigma interpretif dengan metode literature review atau telaah literatur. Perpajakan dengan segala kebijakan dan praktiknya erat kaitannya dengan masyarakat secara umum maupun WP yang memiliki hubungan saling mempengaruhi. Paradigma interpretif digunakan dalam penelitian ini untuk menggali dan menjelaskan hubungan antara perpajakan dan kebijakan perpajakan dalam sosiologi. Hubungan saling mempengaruhi antara pajak (dan kebijakannya) dengan masyarakat digali untuk dapat menjelaskan hubungan antara tindakan dan makna tindakan tersebut dan pesan yang dapat diambil (Lannai et al., 2014). Melalui pemahaman yang mendalam mengenai kebijakan pada sistem WHT pada perpajakan Indonesia dan tindakan atau respon masyakarat (WP) berkaitan dengan sistem ini, maka dapat diajukan usulan untuk memaksimalkan sistem WHT di Indonesia.

Pengumpulan data dalam penelitian ini adalah dengan mengumpulkan berbagai literatur berkaitan dengan tema utama artikel ini yakni withholding tax. Pada riset yang berjudul The Place of Literature Review in Grounded Theory Research oleh Dunne (2011) menyatakan bahwa literature review merupakan pondasi yang penting dalam membangun riset dan memiliki posisi penting dalam riset grounded theory. Kami menyimpulkan bahwa posisi penting telaah literatur untuk penelitian grounded theory ini adalah pada struktur umum grounded theory, yakni struktur umum tersebut berupa teori dan perbedaannya dengan literatur yang ada (Creswell, 2007:80).

Beberapa manfaat dari penelitian telaah literatur yang kami tekankan dalam penulisan artikel ini antara lain: 1) mengidentifikasi hubungan antara teori atau konsep dengan praktik, 2) membedakan penelitian yang patut dan layak dicontoh, 3) menghindari replikasi yang tidak disengaja dan tidak perlu, 4) mengidentifikasi kekuatan dan kelemahan dari berbagai pendekatan penelitian yang telah dimanfaatkan (Onwuegbuzie, Leech, \& Collins, 2012). Secara umum penelitian dengan metode ini akan dapat meningkatkan kemampuan membaca dan memahami penelitian akademik yang mana kemampuan tersebut adalah penting (Gordon \& Porter, 2009).

\section{PEMBAHASAN}

\section{Kinerja Perpajakan 2015 dan Kepatuhan Wajib Pajak}

Sampai dengan 30 September 2015 realisasi penerimaan pajak Indonesia masih mencapai $\mathrm{Rp} 686,274$ triliun atau $53,02 \%$ dari target penerimaan pajak yang ditetapkan sesuai APBN-P 2015 sebesar Rp 1.294,258 triliun (Pajak.go.id, 2015). Penerimaan tersebut masih sangat jauh di bawah target, apalagi saat ini telah mendekati trimester terakhir tahun 2015 akan berakhir. Beberapa tolok ukur yang dapat digunakan untuk mengukur kinerja perpajakan antara lain melalui tax ratio dan tax coverage.

Tax compliance rate yang rendah merupakan masalah besar bagi bangsa Indonesia (Pudjono, 2014). Rendahnya tax coverage ${ }^{1}$ juga merupakan permasalahan utama yang serius (Pajak.go.id, 17/10/2012; Finansial.bisnis.com, 16/06/2014). Rendahnya tax coverage berakibat pada sulitnya mengejar target tax ratio ${ }^{2}$. Banyak daerah di Indonesia yang memiliki potensi ekonomi tinggi, namun tidak dapat terjangkau oleh petugas pajak, sehingga pada pertengahan tahun 
2014 tax coverage ratio Indonesia hanya $50 \%$ dari angka maksimal $70 \%$ (Finansial.bisnis.com, 16/06/2014).

Implikasi dari ketidakpatuhan wajib pajak adalah masih rendahnya tax ratio Indonesia yang hanya berada pada level $12 \%$ pada tahun 2014 (Hidayat, 2014). Menurut data bank dunia tax ratio Indonesia paling rendah dibandingkan dengan negara-negara Asia Tenggara. Perbandingan tax ratio negara-negara Asia Tenggara dan Australia pada tahun 2012 adalah: 1) Indonesia (12\%), 2) Filipina $(12,9 \%), 3)$ Singapura $(14 \%), 4)$ Malaysia $(16,1 \%), 5)$ Thailand $(16,5 \%)$, dan 6) Australia (21,4\%) (worldbank.org, 23/06/2015). Rendahnya tax ratio merupakan titik puncak dari tidak efektifnya implementasi SAS (Belkaoui, 2004; Kusumawati, 2005; Permita et al., 2014; Saad, 2012, 2014).

Meskipun jika dibandingkan dengan negara lain tax ratio Indonesia termasuk pada level yang rendah. Namun akan sulit membandingkan kinerja perpajakan Indonesia di dalam pergaulan perekonomian internasional. Hal ini karena adanya perbedaan formula dan dasar perhitungan tax ratio Indonesia yang tidak menggunakan standar OECD (Amir, 2014; dpr.go.id, 2003; Prasetyo, 2014). Indonesia tidak memasukkan pajak daerah dan sumber daya alam dalam perhitungan tax rationya (Pajak.go.id, 2012a; Setiyaji, 2007). Namun tax ratio akan dapat digunakan untuk indikator melihat perkembangan penerimaan pajak setiap tahun (Amir, 2014).

Kepatuhan dapat diartikan sebagai bentuk loyalitas yaitu sikap atau perilaku sebagai loyalis murni (Lee et al, 2001). Bidang perpajakan mengartikan hal ini sebagai pemenuhan kewajiban sebagai seorang WP dengan dimensi lengkap dan benar dalam pelaksanaannya. Kewajiban seorang WP secara garis besar adalah mendaftarkan diri pada kantor Direktorat Jenderal Pajak (DJP), selanjutnya memotong/memungut, membayar, dan melaporkan pajak, bersikap kooperatif saat diperiksa serta memberikan data yang berkaitan dengan perpajakan (DJP, 2015).

Teori pertama yang mendefinisikan kepatuhan pajak adalah teori yang dikemukakan oleh Allingham \& Sandmo (1972), yang melihat dari sudut pandang ekonomika. Bahwa manusia adalah makhluk ekonomi yang akan cenderung untuk tidak membayarkan pajaknya atau membayar namun tidak sesuai dengan yang seharusnya dibayarkan. Menurut teori ini untuk meningkatkan kepatuhan pajak, maka perlu dilakukan dengan penerapan variabel deterrence berupa sanksi atau denda, sehingga kepatuhan yang akan dihasilkan dengan penerapan variabel deterrence adalah forced tax compliance. Pendekatan ini menganggap bahwa WP berpotensi untuk melakukan tindakan manipulasi. Namun penelitian lain menunjukkan bahwa pendekatan deterrence (pemeriksaaan dan hukuman) tidak efektif untuk meningkatkan kepatuhan (Kaplanoglou \& Rapanos, 2015). Hal ini karena tax ratio hanya dapat dicapai melalui kepatuhan pajak sukarela (Kirchler, Hoelzl, \& Wahl, 2008). Pendekatan variabel deterrence hanya akan efektif pada tujuan jangka pendek, yakni menghukum WP yang tidak patuh, sedangkan tujuan jangka panjang yang penting adalah mempengaruhi perilaku WP (Rosdiana \& Irianto, 2014: 19).

Pendekatan psikologi kemudian digunakan untuk melakukan penelitian mengenai perilaku pembayar pajak. Teori lain yang mendominasi pada penelitian kepatuhan pajak yang berasal dari psikologi yakni Theory Planned of Behavior (TPB) oleh Ajzen (1991). Teori ini juga telah digunakan dalam berbagai penelitian berkaitan dengan keperilakuan. Asumsi dari teori ini adalah menganggap bahwa terdapat kepastian di masa mendatang. Sedangkan dalam perpajakan, masa depan merupakan hal yang tidak pasti, sehingga orientasi WP akan mengarah pada ketidakpastian (Damayanti, Sutrisno, Subekti, \& Baridwan, 2015).

Faktor- Faktor yang Mempengaruhi Kepatuhan Sukarela Wajib Pajak 
Banyak penelitian yang telah dilakukan mengenai faktor-faktor yang mempengaruhi kepatuhan sukarela wajib pajak. Beberapa penelitian tersebut merumuskan bahwa anteseden voluntary tax compliance antara lain adalah: 1) Religiusitas atau spiritualitas (Darmayasa \& Aneswari, 2015; Fidiana, 2014b; Torgler, 2003), 2) Moral Pajak (Goksu \& Sahpaz, 2015; Torgler, 2012), 3) Budaya (Lubian \& Zarri, 2011; Torgler, 2012), 4) Pendidikan atau informasi perpajakan (Ali, Fjeldstad, \& Sjursen, 2014; Goksu \& Sahpaz, 2015), dan 5) Rasa percaya dan kekuasaan otoritas (Gangl, Hofmann, \& Kirchler, 2015; Kogler, Batrancea, et al., 2013).

Individu yang menginternalisasi ajaran agamanya, akan berimplikasi pada segala tindakannya (Darmayasa \& Aneswari, 2015). Religiusitas dianggap memiliki pengaruh yang besar pada tindakan seseorang (Abu-Rayya \& White, 2010; Brañas-garza, Espín, \& Neuman, 2013; Lehrer, 2004). Diyakini aspek spiritualitas mampu membendung niat orang untuk melakukan tindakan yang melanggar norma. Tindakan penggelapan pajak merupakan tindakan yang menyalahi norma dan mampu dibendung oleh aspek spiritualitas dan religiusitas wajib pajak (Basri, 2014; Fidiana, 2014a; Weaver, 2002).

Moral pajak didefinisikan oleh Goksu \& Sahpaz (2015) sebagai motivasi intrinsik kepatuhan sukarela dalam membayar pajak yang dipengaruhi oleh berbagai faktor seperti pendidikan, demografi, latar belakang ekonomi atau sosio-budaya individu. Penelitian lain dilakukan oleh Torgler, Demir, Macintyre, \& Schaffner (2008) di USA dan Turki yang menunjukkan hasil bahwa faktorfaktor seperti administrasi pajak, sistem pajak dan persepsi beban pajak, kesadaran pajak, persepsi kepatuhan, rasa percaya pada otoritas, pemerintah dan lain-lain, kualitas institusi seperti tingkat korupsi, keinginan untuk mematuhi dan religiusitas memiliki dampak yang kuat pada moral pajak.

Faktor kepercayaan terhadap otoritas pajak di Indonesia sempat merosot dengan terungkapnya kasus mafia pajak Gayus Tambunan, yang juga tersandung kasus penyuapan penjaga tahanan dan pencucian uang (nasional.kompas.com, 2013) serta kasus korupsi Dhana Widyatmika yang diduga berkaitan (nasional.kompas.com, 2012). Meskipun Indeks Persepsi Korupsi Indonesia naik 7 peringkat per Desember 2014 menjadi ranking 107 di dunia, namun data KPK menunjukkan bahwa korupsi paling banyak masih ada pada kementerian dan lembaga pemerintah (news.liputan.6.com, 2014). WP yang sudah memahami peran pajak sebagai sumber pembiayaan negara pun akan berpikir ulang untuk patuh terhadap peraturan pajak, jika pegawai pajaknya sendiri tidak patuh dan malah menyelewengkan iuran wajib rakyat.

Kemajuan dalam hal budaya pajak akan berpengaruh positif pada reformasi perpajakan yang bertujuan pada peningkatan kepatuhan pajak (Carolina, Meythi, \& Martusa, 2012). Kemajuan budaya pajak sangat dipengaruhi dengan informasi atau pendidikan pajak yang mumpuni (Carolina et al., 2012). Informasi atau pendidikan pajak akan berpengaruh positif pada kepatuhan pajak (Park \& Hyun, 2003). Beberapa pihak memiliki kewajiban dalam memberikan pendidikan atau informasi pajak ini seperti pemerintah, akademisi, dan konsultan pajak (Carolina et al., 2012; Darmayasa \& Aneswari, 2015). Adanya Tax Center dan ICATAS (Integrated Center for Accounting Taxation and Assurance Services) di berbagai universitas sebagai bentuk kerjasama dengan Dirjen Pajak juga dapat membantu program sosialisasi yang melayani bantuan pengisian SPT dan update informasi terkini tentang peraturan perpajakan.

Rasa percaya pada otoritas pajak dan kekuasaan otoritas pajak merupakan dua hal yang termasuk dalam slippery slope framework (Kirchler et al., 2008; Kogler, Muehlbacher, \& Kirchler, 2013). Penelitian yang dilakukan oleh Prinz et al. (2014) mengasumsikan bahwa terdapat dua grup WP yakni compliance minded dan evasion minded. Melalui pengelompokan 
jenis WP tersebut, maka dapat memberikan gambaran pada pemerintah mengenai karakteristik kerja otoritas pajak yang paling efektif pada warga negara tersebut. Apakah WP akan cenderung efektif jika kebijakan cenderung koersif atau persuasif, sehingga dapat menentukan alat kebijakan yang paling tepat untuk meningkatkan kepatuhan pajak.

Sehingga pengampunan bukanlah satu-satunya faktor yang dapat mendorong seorang WP untuk taat secara sukarela. Berbagai faktor yang diajukan dalam penelitian terdahulu merupakan tindakan pencegahan sebelum ketidakpatuhan WP terjadi, sedangkan pengampunan merupakan penanganan. Penanganan tanpa pencegahan akan sia-sia, karena hal yang sama akan terus terjadi. Hal ini dapat diibaratkan seperti mengulang "dosa" yang sama dan tidak menimbulkan jera.

\section{Langkah yang Harus Ditempuh untuk Meningkatkan Kepatuhan Pajak}

Salah satu ciri masyarakat yang modern adalah kepatuhan sukarela terhadap segala peraturan perpajakan yang dikeluarkan pemerintah (van Dijke \& Verboon, 2010). Menurut Direktur Jenderal Pajak Sigit Priadi Pramudito, jika dibandingkan dengan Amerika, maka kepatuhan pajak Indonesia yang merupakan negara berkembang jauh di bawah, yakni hanya 30\% sedangkan di Amerika hampir 100\% (Pratiwi, 2015). Penghasilan pajak di Amerika tersebut mampu untuk menggaji warga negara yang miskin dan menggratiskan seluruh layanan di Rumah Sakit (RS) (Pratiwi, 2015). Bahkan jika dibandingkan dengan negara tetangga, Malaysia, pada 2012 kepatuhan pajak negara tersebut hampir 80\% (S. Manurung, 2013).

Meskipun pajak merupakan kontribusi wajib yang insentifnya tidak didapat secara langsung. Namun pemerintah perlu mencermati, bahwa untuk meningkatkan kepatuhan pajak secara sukarela, maka warga harus mendapatkan bukti secara riil bahwa pajak yang dibayarkan ada bukti yang dapat dirasakan oleh warga negara. Hal ini disebut dengan teori psikologi fiskal. Teori Psikologi Fiskal menekankan pada hilangnya motivasi dari wajib pajak untuk membayar pajak disebabkan oleh tidak adanya keuntungan secara langsung dari pembayaran pajak (Hasseldine \& Bebbington, 1991).

Berdasarkan teori Psikologi fiskal tersebut, meskipun secara langsung masyarakat tidak dapat merasakan dampak dari pajak yang dibayarkan, namun pemerintah Indonesia harus transparan. Pemerintah harus secara terbuka menunjukkan bahwa pajak tersebut memang digunakan untuk pengadaan public goods, bukan semenamena digunakan pemerintah (Rosdiana \& Irianto, 2014 : 26). Manfaat pajak pada definisi pajak kontemporer akhirnya berkembang, bahwa manfaat yang dirasakan bagi para pembayar pajak bisa berupa kemudahan akses mengenai informasi pemerintahan, sehingga akan membangun social trust dari masyarakat melalui transparansi tersebut (Rosdiana \& Irianto, 2014 : 25)

Teori kedua yang dapat diadopsi pemerintah Indonesia untuk meningkatkan kepatuhan pajak sukarela adalah melalui slippery slope framewok yang diusulkan pertama kali oleh Kirchler et al. (2008). Dua hal yang mendasari kepatuhan pajak sukarela berdasarkan slippery slope framework, yakni kekuatan otoritas dan rasa percaya terhadap otoritas (Kirchler et al., 2008; Kogler, Muehlbacher, et al., 2013). Sehingga berdasarkan teori ini pemerintah perlu mengenali karakteristik serta budaya warga Indonesia yang tersebar dari Sabang sampai Merauke. Pendekatan apa yang paling sesuai untuk dilakukan, apakah dengan menunjukkan kekuatan melalui variabel deterrence atau dengan pendekatan yang mampu meningkatkan kepercayaan.

Kami memandang bahwa dua pendekatan dalam slippery slope framework sama-sama perlu untuk dilaksanakan. Artinya pemerintah perlu melakukan hal-hal seperti penegakan aturan dan pengenaan sanksi bagi WP yang melakukan pelanggaran maupun 
bagi otoritas pajak yang melakukan moral hazard tanpa ada tebang pilih, sehingga hal tersebut akan memberi pelajaran bagi pelaku dan otomatis akan meningkatkan rasa percaya terhadap otoritas. Pendekatan slippery slope framework yang pertama ini sesuai dengan teori yang diajukan Allingham \& Sandmo (1972) yang berasumsi bahwa tidak ada individu yang akan dengan rela membayarkan pajak, sehingga perlu diterapkan hukuman, sanksi dan denda yang berat untuk meningkatkan kepatuhan. Namun pendekatan variabel deterrence hanya akan menghasilkan kepatuhan sementara atau jangka pendek, yakni menghukum WP yang tidak patuh (Rosdiana \& Irianto, 2014 : 19), bahkan beberapa peneliti berpendapatan pendekatan variabel deterrence tidak efektif dan tidak mampu menjelaskan kepatuhan wajib pajak (Darmayasa \& Aneswari, 2015; Kirchler et al., 2008; Kogler, Batrancea, et al., 2013).

Maka pemerintah perlu melakukan berbagai upaya untuk meningkatkan kepercayaan dari warga negara terhadap otoritas. Menurut Torgler et al. (2008) maka beberapa hal seperti administrasi pajak, sistem pajak dan kualitas institusi seperti tingkat korupsi akan sangat berpengaruh pada kepatuhan pajak. Kualitas pelayanan yang diberikan oleh petugas pajak dalam bentuk penyuluhan, pengawasan, dan pelayanan kepada wajib pajak mempengaruhi kepatuhan pajak (Kusumawati, 2005). Penelitian yang dilakukan oleh Lisi
(2014) menunjukkan bahwa pembangunan hubungan yang dilandasi rasa percaya jauh lebih efektif dari pada menerapkan variabel deterrence seperti teori yang diajukan Allingham \& Sandmo (1972). Komunikasi yang baik juga akan menurunkan tax phobia yang dialami oleh warga negara. Pengetahuan warga terhadap regulasi dan perpajakan juga akan meningkatkan kepercayaan pada otoritas sehingga akan mendorong kepatuhan pajak (Darmayasa \& Aneswari, 2015).

\section{Mekanisme dan Prinsip Dasar Pemotongan Pajak dengan sistem Withholding Tax di Indonesia}

Dasar hukum withholding tax system adalah UU No 36 Tahun 2008 tentang Perubahan Keempat atas UU No 7 Tahun 1983 tentang Pajak Penghasilan. Beberapa pasal-pasal UU Pajak Penghasilan yang menggunakan WHT adalah: Pasal 4 (2), Pasal 20, Pasal 21, Pasal 22, Pasal 23, Pasal 24 dan Pasal 26. Melalui sistem WHT ini, perusahaan dapat menggunakan metode penghitungan gross base atau nett base (Rosdiana \& Irianto, 2014:55-56). Pada gross base $\mathrm{PPh}$ terutang ditanggung atau ditunjang oleh pemotong (withholder), sedangkan pada nett base maka $\mathrm{PPh}$ terutang akan ditanggung oleh pemotong (Rosdiana \& Irianto, 2014, 55-56).

Mekanisme hubungan antara WP, DJP dan pihak ketiga dalam withholding tax dapat dilihat pada bagan berikut:

Bagan 1. Hubungan WP, DJP dan Pemberi Kerja dalam Withholding System

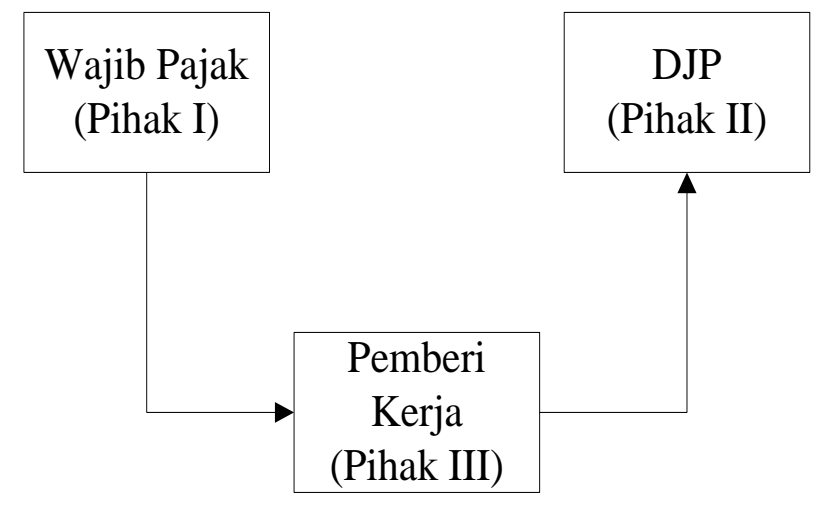


I Nyoman D. Yuyung R. A., Elana E. Y. 2016

InFestasi Vol.12, No.2, Desember

\section{Sumber: Tim Peneliti}

Berdasarkan bagan tersebut maka pemberi kerja atau pemberi penghasilan akan melakukan pemotongan pajak atas WP sebagai pihak pertama termasuk membayarkannya ke Bank Persepsi dan melaporkannya ke DJP. Pihak ketiga berkewajiban membuat bukti potong sebagai bukti telah memotong $\mathrm{PPh}$ dari pihak pertama. Bukti potong PPh non final yang dibuat oleh pihak ketiga akan digunakan sebagai kredit pajak bagi pihak pertama dalam perhitungan $\mathrm{PPh}$ terutang akhir tahun.

Withholding system dianggap merupakan gabungan antara SAS dan Official Assessment System (OAS), sehingga dalam Rosdiana \& Irianto (2014 : 107) WHT ini disebut dengan hybrid system. Basis pajak yang termasuk dalam pemotongan dengan sistem WHT antara lain adalah: pemotongan atas gaji atau penghasilan $(\mathrm{PPh} 21, \mathrm{PPh} 22, \mathrm{PPh}$ 23, PPh 26), dividen, bunga selanjutnya dalam (Rosdiana \& Irianto, 2014:108) dijelaskan bahwa diperluas pada jasa profesional, sewa serta pada semua penghasilan usaha lain. Pada semua basis pemotongan WHT, hanya pajak atas gaji yang menggunakan prinsip pay as you earn (PAYE) (Rosdiana \& Irianto, 2014:108).

\section{Efektivitas dan Efisiensi Withholding Tax dalam Memaksimalkan Penerimaan Pajak}

Indonesia merupakan negara kepulauan dengan cakupan wilayah daratan dan lautan yang luas. Kondisi geografis seperti ini akan sulit untuk melakukan proses kontrol dan pengawasan perpajakan. Maka diperlukan suatu sistem yang akan mempermudah kontrol serta pengawasan yakni melalui WHT.

WHT akan mempermudah proses pengawasan sebab DJP hanya perlu fokus pada para pemotong pajak yang jumlahnya tidak sebanyak WP. Sehingga proses pengawasan akan dapat lebih efektif dan efisien. Sistem ini juga selalu efektif karena akan mampu mengumpulkan pajak tepat waktu, yakni pada saat WP menerima penghasilan, sehingga cashflow pemerintah akan terjaga (Advianto, 2014). Sedangkan pemotongan $\mathrm{PPh}$ akan mencerminkan prinsip bahwa pajak tersebut dipotong pada saat kemampuan ekonomi WP tinggi, sebab dipotong pada saat WP menerima penghasilan. Artinya pemotongan PPh melalui WHT tidak akan mengganggu cashflow WP dan pemotong (Advianto, 2014).

WHT juga akan mempermudah pengumpulan pajak tanpa biaya administrasi yang tinggi karena fiskus meminimalkan perannya dan memberi kepercayaan pada pemotong. Selain itu WHT akan efektif dalam memingkatkan kepatuhan pajak sukarela, karena pembayar pajak secara tidak langsung telah membayarkan pajaknya (A. Manurung, 2012). Artinya bagi WP akan lebih praktis karena pajak telah terbayar tanpa melalui proses menghitung, memotong, menyetorkan, dan melaporkan (4M) seperti pada SAS.

Beberapa manfaat atau kelebihan sistem WHT antara lain yang pertama, memberikan kontribusi siginifikan pada penerimaan negara (Rosdiana \& Irianto, 2014: 109). Kedua, mudah untuk dilaksanakan serta hemat pada administrative cost, sebab fiskus hanya perlu fokus pada kepatuhan pemotong pajak (Rosdiana \& Irianto, 2014:109110). Ketiga, merupakan penerapan prinsip convenience of tax system (A. Manurung, 2012).

Maka apabila digambarkan dalam suatu bagan mengenai efektivitas WHT adalah sebagai berikut: 
Bagan 2. Efektivitas Withholding System

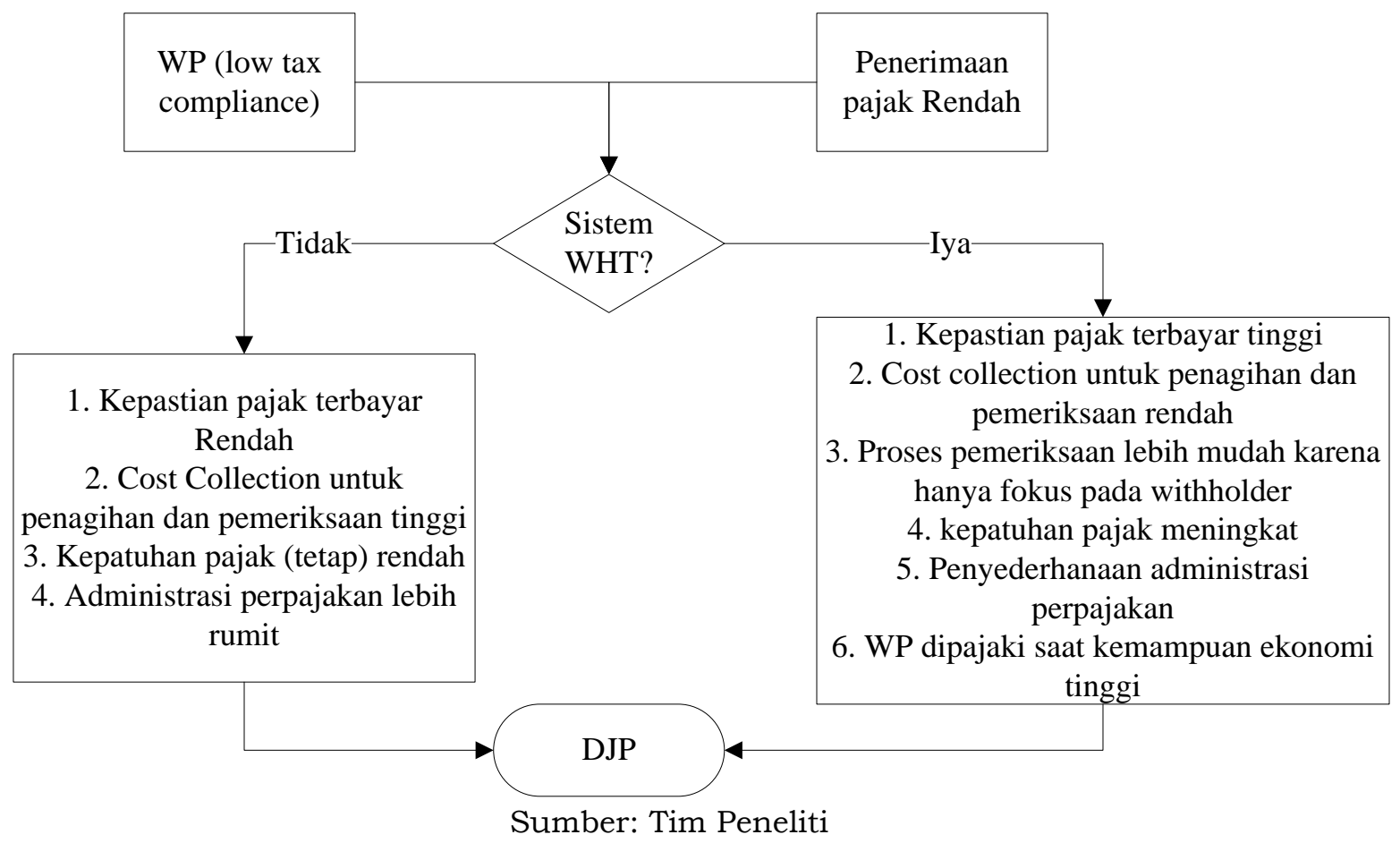

WHT merupakan sistem paling efektif yang dapat menjamin kepastian terbayarnya pajak. Pemotong pajak yang berasal dari pemberi kerja selaku pihak ketiga, justru akan cenderung lebih disiplin dalam menghitung, memotong dan membayarkan pajak. Sistem WHT juga mampu untuk meningkatkan kepatuhan WP, hal ini karena antara WP dan pihak pemotong memiliki kepentingan yang berbeda. Tentu saja WHT sesuai dengan negara Indonesia yang kepatuhan pajaknya rendah. Melalui WHT juga akan menghemat cost collection tax untuk penagihan dan pemeriksaan, sebab DJP hanya perlu fokus pada withholder yang jumlahnya jauh lebih sedikit bila dibandingkan dengan jumlah WP. Terakhir WP yang dipajaki melalui WHT berada dalam kemampuan ekonomi yang tinggi.

\section{Strategi Tax Effort Memaksimalkan Penerimaan Pajak melalui Skema Baru Sistem Withholding Tax}

Efektivitas pengumpulan pajak melalui WHT ditunjukkan di beberapa negara bahwa porsi penerimaan pajak dari WHT memiliki persentase yang signifikan. Di Amerika Serikat sendiri porsi withholding $\operatorname{tax}$ mencapai $70 \%$ dari penerimaan negara tersebut sehingga penerapannya sangat diperhitungkan oleh Internal Revenue Service (IRS) (Ompusunggu, 2009). Demikian juga di Indonesia Kontribusi WHT terhadap porsi penerimaan pajak mengalami pertumbuhan (Handoko, 26/06/2015).

Memperhatikan efektivitas dan efisiensi yang didapatkan melalui WHT sistem maka perlu dilakukan maksimalisasi tax effort dengan sistem ini. Pemerintah perlu mendesain skema yang akan meningkatkan penerimaan pajak melalui WHT. Skema pajak yang merupakan tax effort melalui WHT tersebut antara lain dengan menambah tax base yang dapat dijangkau pada pemotongan melalui WHT. Beberapa jenis pajak kategori Non Final yang masih memungkinkan, bisa diubah menjadi 
pajak Final sehingga akan mempermudah mekanisme dalam pemotongan WHT.

Skema lainnya adalah penerapan sanksi bagi pihak ketiga perlu dilakukan telaah ulang. Pemerintah perlu memberikan insentif dengan cara lain agar pihak ketiga tidak terbebani menjalankan amanat dalam melakukan pemotongan pajak. Misalnya dengan memberikan reward bagi pemotong pajak yang disiplin dan taat. DJP telah sangat dibantu dan dimudahkan dengan adanya kerjasama yang baik dari para pemberi kerja yang disiplin dan patuh mendukung sistem WHT ini, sehingga akan lebih fair apabila DJP memberikan insentif berupa reward bukan sanksi yang justru akan memperbesar rasa tax phobia.

Kemudian DJP perlu diberi akses pada data perbankan dengan bekerjasama dengan Pusat Pelaporan dan Analisis Transaksi Keuangan (PPATK). Selama ini akses DJP terhadap data perbankan masih terhalang dengan UU Kerahasiaan Perbankan. Selama DJP belum atau tidak memiliki akses yang layak ke dalam data perbankan, maka kebijakan apapun yang dikeluarkan mengenai perpajakan akan sulit untuk dapat berjalan efektif. Skema terakhir adalah perlunya administrasi perpajakan yang baik melalui Single Identification Number (SIN) untuk menjaring wajib pajak baru (Arnold, 2012; Prastowo, 2015).

\section{PENUTUP}

Kepatuhan pajak di Indonesia masih dalam kategori rendah dan perlu dilakukan upaya untuk meningkatkan kepatuhan tersebut. Melalui teori psikologi fiskal, meskipun tidak secara langsung warga negara merasakan manfaat pajak, namun masyarakat harus memiliki kemudahan akses terhadap informasi pemerintah dan pemerintah harus transparan mengenai penggunaan pajak pada pengadaan public goods. Bentuk jaminan transparansi ini otoritas perlu membuat laporan estimasi pengeluaran pajak rutin disertai evaluasi berkala dengan pengukuran tertentu (Arnold, 2012). Melalui slippery slope framework pemerintah juga harus: 1) secara tegas menghukum dan memberi sanksi WP dan ototitas pajak yang melakukan pelangggaran tanpa tebang pilih, sehingga akan memberikan pelajaran dan meningkatkan kepercayaan, 2) memperbaiki administrasi pajak, sistem pajak dan kualitas instansi seperti menurunkan tingkat korupsi, 3) membangun komunikasi yang baik dan harmonis melalui berbagai penyuluhan atau tax education bentuk lain sehingga akan menurunkan tax phobia dan meningkatkan kepatuhan pajak.

Melalui sistem withholding tax WP dipotong $\mathrm{PPh}$ pada saat kemampuan ekonomi tinggi sehingga tidak mengganggu cashflow WP. Ketiga, beberapa manfaat WHT yang menunjukkan efektivitas dan efisiensi sistem ini antara lain: 1) sistem withholding tax mampu menjamin kepastian terbayarnya pajak, 2) terbukti efektif dan efisien dalam memaksimalkan penerimaan pajak, 3) menghemat cost collection tax serta mempermudah dalam penagihan pengawasan, karena mempersempit objek pemeriksaan bukan pada WP pribadi namun pada pemberi kerja yang melakukan pemotongan, 4) menghemat administrative cost, karena fiskus tidak banyak turun tangan melainkan memberi kepercayaan pada pemotong pajak sebagai pihak ketiga, 4) menyederhanakan administrasi perpajakan bagi WP , 5) mampu meningkatkan kepatuhan pajak dan 6) WP dipajaki pada saat kemampuan ekonominya tinggi.

Beberapa tax effort yang perlu dilakukan pemerintah dengan memperbarui skema pada WHT ini antara lain 1) memperluas tax basis, 2) mengarahkan pemotongan pajak yang belum bersifat final ke dalam pajak yang bersifat final dalam skema withholding tax agar penerimaan pajak makin optimal, 3) memberikan reward (bukannya sanksi) bagi pihak ketiga yang disiplin dan taat mendukung WHT, 4) membuka akses DJP pada data perbankan melalui kerjasama dengan PPATK, 5) memperbaiki administrasi perpajakan melalui Single Identification 
Number (SIN) untuk menjaring wajib pajak baru.

Penelitian ini hanya mencakup permasalahan WHT yang bersifat kontekstual yang berasal dari literaturliteratur terkini yang menggambarkan praktik WHT di Indonesia saat ini. Penelitian selanjutnya perlu diperdalam dengan menggunakan metode atau paradigma lain untuk mengungkap dan menggali permasalahan WHT yang lebih riil. Sehingga akan memperkaya solusi dan masukan berkaitan dengan aturan WHT di Indonesia.

\section{DAFTAR PUSTAKA}

Abu-Rayya, H. M., \& White, F. A. (2010). Acculturation orientations and religious identity as predictors of Anglo-Australians' attitudes towards Australian Muslims. International Journal of Intercultural Relations, 34(6), 592-599. http://doi.org/10.1016/j.ijintrel.20 10.02.006

Advianto, L. H. S. (2014). Pemotongan dan Pemungutan Pajak Penghasilan. Retrieved September 30, 2015, from http://www.bppk.kemenkeu.go.id/ publikasi/artikel/167-artikelpajak/12682-pemotongan-danpemungutan-pajak-penghasilan

Ajzen, I. (1991). The theory of planned behavior. Organizational Behavior and Human Decision Processes, 50, 179-211.

http://doi.org/10.1016/07495978(91)90020-T

Ali, M., Fjeldstad, O.-H., \& Sjursen, I. H. (2014). To Pay or Not to Pay? Citizens' Attitudes Toward Taxation in Kenya, Tanzania, Uganda, and South Africa. World Development, 64, 828-842. http://doi.org/10.1016/j.worlddev. 2014.07.006

Allingham, G. M., \& Sandmo, A. (1972). Income Tax Evasion: A Theoretical Analysis. Jounal of Public Economics, 1, 323-338.

Amir, H. (2014). Potensi Pajak dan Kinerja Pemungutannya. http://www.kemenkeu.go.id/sites/
default/files/Pajak Potensi Dan Pengumpulannya.pdf.

Andini, L. G., \& Sumadi, I. K. (2014). Analisis Penerapan Tax Review atas Pajak Penghasilan Badan dan Withholding Tax pada Hotel X. EJurnal Akuntansi Universitas Udayana, 1, 69-87.

Arnold, J. (2012). Improving the Tax System in Indonesia.

Basri, M. Y. (2014). Efek Moderasi Religuisitas dan Gender Terhadap Hubungan Etika Uang (Money Ethics) dan Kecurangan Pajak (Tax Evasion). In Simposium Nasional Akuntansi XVII. Mataram: Universitas Mataram, 24-27 September 2014.

Belkaoui, A. R. (2004). Relationship Between Tax Compliance Internationally and Selected Determinants of Tax Morale. Journal of International Accounting, Auditing and Taxation, 13(2), 135143.

http://doi.org/10.1016/j.intaccaud tax.2004.09.001

bisnis.com. (2014). Rasio Pemungutan Pajak Masih Rendah. Retrieved July 2, 2015, from finansial.bisnis.com

Brañas-garza, P., Espin, A. M., \& Neuman, S. (2013). Effects of Religiosity on Social Behaviour: Experimental Evidence from a Representative Sample of Spaniards. IZA Discussion Paper, (7683).

Carolina, V., Meythi, \& Martusa, R. (2012). Tax Culture: Dasar Pelaksanaan Reformasi Perpajakan Menuju Kepatuhan Sukarela. In Proceeding Simposium Nasional Perpajakan III " Road Map Reformasi Perpajakan Indonesia menuju Good Governance ". Madura: Universitas Trunojoyo, 1314 Desember 2012.

Creswell, J. W. (2007). Qualitative Inquiry $\&$ Research Design Choosing among Five Approaches (2nd ed.). USA: Sage Publications Inc.

Damayanti, T. W., Sutrisno, Subekti, I., \& Baridwan, Z. (2015). The Role of Taxpayer's Perception of the Government and Society to Improve Tax Compliance. Accounting and 
I Nyoman D. Yuyung R. A., Elana E. Y.

InFestasi Vol.12, No.2, Desember 2016

Finance Research, 4(1).

http://doi.org/10.5430/afr.v4n1p1 80

Darmayasa, I. N., \& Aneswari, Y. R. (2015). The Ethical Practice of Tax Consultant Based on Local Culture. In Book of Conference Proceedings 2nd Global Conference on Business\&Social Sciences 17th-18th September 2015 Bali, Indonesia (p. 169).

Data.worldbank.org. (2015). Tax revenue (\% of GDP).

dpr.go.id. (2003). Meningkatkan Tax Ratio Indonesia.

Dunne, C. (2011). The place of the literature review in grounded theory research. International Journal of Social Research Methodology, 14(2), 111-124.

http://doi.org/10.1080/13645579. 2010.494930

Fidiana. (2014a). Eman dan Iman: Dualisme Kesadaran dan Kepatuhan. In Simposium Nasional Akuntansi XVII. Mataram: Universitas Mataram, 24-27 September 2014.

Fidiana. (2014b). Non-Compliance Behavior in the Frame of Ibn Khaldun. International Journal of Business and Behavioral Sciences, 4(6), 30-48.

Gangl, K., Hofmann, E., \& Kirchler, E. (2015). New Ideas in Psychology Tax Authorities' Interaction with Taxpayers: A Aonception of Compliance in Social Dilemmas by Power and Trust. New Ideas in Psychology, 37, 13-23. http://doi.org/10.1016/j.newideap sych.2014.12.001

Goksu, G. G., \& Sahpaz, K. I. (2015). Comparison of Tax Morale of Turkish and Spanish Higher Education Students: The Samples of Sakarya University and the University of Zaragoza. Procedia Social and Behavioral Sciences, 186, 222-230. http://doi.org/10.1016/j.sbspro.20 15.04.027

Gordon, T. P., \& Porter, J. C. (2009). Reading And Understanding Academic Research In Accounting: A Guide for Students. Global
Perspectives on Accunting Education, 6, 25-45.

Handoko, P. (2015). Pertumbuhan Penerimaan Pajak Masih Melambat. Retrieved September 30, 2015, from http://pemeriksaanpajak.com/201 5/06/26/pertumbuhanpenerimaan-pajak-masihmelambat/

Hasseldine, D. J., \& Bebbington, K. J. (1991). Blending Economic Deterrence and Fiscal Psychology Models in The Design of Responses to Tax Evasion: The New Zealand Experience. Journal of Economic Psychology, 12, 299-324. http://doi.org/10.1016/01674870(91)90018-O

Hidayat, A. (2014). Kewenangan Otoritas Pajak untuk Meningkatkan Tax Ratio.

Kaplanoglou, G., \& Rapanos, V. T. (2015). Why do people evade taxes? New experimental evidence from Greece. Journal of Behavioral and Experimental Economics, 56, 21-32. http://doi.org/10.1016/j.socec.201 5.02 .005

Kirchler, E., Hoelzl, E., \& Wahl, I. (2008). Enforced versus voluntary tax compliance: The "slippery slope" framework. Journal of Economic Psychology, 29(2), 210-225. http://doi.org/10.1016/j.joep.2007 .05 .004

Kogler, C., Batrancea, L., Nichita, A., Pantya, J., Belianin, A., \& Kirchler, E. (2013). Trust and power as determinants of tax compliance: Testing the assumptions of the slippery slope framework in Austria, Hungary, Romania and Russia. Journal of Economic Psychology, 34, 169-180. http://doi.org/10.1016/j.joep.2012 .09 .010

Kogler, C., Muehlbacher, S., \& Kirchler, E. (2013). Trust, power, and tax compliance: Testing the "slippery slope framework " among selfemployed taxpayers Christoph Kogler Stephan Muehlbacher. WU International Taxation Reserach Paper Series, 05, 2-18.

Kusumawati, T. I. (2005). Analisis Perilaku Wajib Pajak Orang Pribadi 
Terhadap Pelaksanaan Self Assesment System. In Simposium Riset Ekonomi II. Surabaya: 23-24 November 2005.

Lannai, D., Sudarma, M., Irianto, G., \& Ludigdo, U. (2014). Phenomenology Study About Performance Meaning At Indonesia Foundation (Case Studies At Wakaf Foundation Of Indonesian Muslim University). International Journal of Business and Management Invention, 3(5), 816.

Lehrer, E. L. (2004). Religion as a Determinant of Economic and Demographic Behavior in the United States. Population and Development Review, 30(4), 707726.

Lisi, G. (2014). The interaction between trust and power: Effects on tax compliance and macroeconomic implications. Journal of Behavioral and Experimental Economics, 53, 24-33.

http: / / doi.org/ 10.1016/j.socec.201 4.07.004

Lubian, D., \& Zarri, L. (2011). Happiness and tax morale: An empirical analysis. Journal of Economic Behavior \& Organization, 80(1), 223-243.

http://doi.org/ 10.1016/j.jebo. 2011 .03 .009

Manurung, A. (2012). Pengaruh Penerapan Withholding Tax System Terhadap Optimalisasi Penerimaan Pajak Penghasilan. Retrieved September 30, 2015, from http: / / andymanurung.blogspot.co.i d/2012/06/penerimaan-pajakpenghasilan.html

Manurung, S. (2013). Kompleksitas Kepatuhan Pajak. Retrieved September 18, 2015, from http: / / www.pajak.go.id/content/ar ticle/kompleksitas-kepatuhanpajak

Ompusunggu, A. P. (2009). Sinkronisasi Penyempurnaan Undang-Undang Pajak Penghasilan terhadap Efektivitas Kebijakan Pajak atas Pemungutan dan Pemotongan Pajak (Withholding Tax). Jurnal Akuntansi, 9(3), 203-220.
Onwuegbuzie, A. J., Leech, N. L., \& Collins, K. M. T. (2012). Qualitative Analysis Techniques for the Review of the Literature. The Qualitative Report, 17(56), 1-28.

Pajak.go.id. (2012a). Dirjen Pajak: “Tax Ratio Indonesia Tinggi, Ada Kesalahan Penghitungan Tax Ratio!"

Pajak.go.id. (2012b). Selayang Pandang Withholding Tax di Indonesia. Retrieved September 30, 2015, from http://www.pajak.go.id/content/se layang-pandang-withholding-tax-diindonesia

Pajak.go.id. (2015). Realisasi Penerimaan Pajak per 31 Agustus 2015. Retrieved September 18, 2015, from http://www.pajak.go.id/content/re alisasi-penerimaan-pajak-31agustus-2015

Palil, M. R., \& Mustapha, A. F. (2011). Factors Affecting Tax Compliance Behaviour in Self Assessment System. African Journal of Business Management, 5(33), 12864-12872. http:/ / doi.org/ 10.5897/ AJBM11.1 742

Park, C.-G., \& Hyun, J. K. (2003). Examining the determinants of tax compliance by experimental data: a case of Korea. Journal of Policy Modeling, 25(8), 673-684. http: / /doi.org/10.1016/S01618938(03)00075-9

Permita, A. C., Fauziati, P., Yulistia, R., \& Minovia, A. F. (2014). Pengaruh Persepsi Wajib Pajak Orang Pribadi atas Pelaksanaan Self Assessment System Terhadap Tindakan Tax Evasion di Kota Padang. In Simposium Nasional Akuntansi XVII. Mataram: Universitas Mataram, 2427 September 2014.

Prasetyo, K. A. (2014). Quo Vadis Tax Ratio Indonesia. http:/ / doi.org/http: / /www.bppk.ke menkeu.go.id

Prastowo, Y. (2015). Pajak dan Ketimpangan. Harian Kompas, p. 7. Jakarta.

Pratiwi, D. A. (2015). Di Amerika, Pajak Bisa Gaji Orang Miskin dan Gratiskan RS. Retrieved September 16, 2015, from http: / / economy.okezone.com/read 
/2015/09/01/20/1206093/diamerika-pajak-bisa-gaji-orangmiskin-dan-gratiskan-rs

Prinz, A., Muehlbacher, S., \& Kirchler, E. (2014). The slippery slope framework on tax compliance: An attempt to formalization. Journal of Economic Psychology, 40, 20-34. http://doi.org/10.1016/j.joep.2013 .04 .004

Pudjono, A. N. S. (2014). Meningkatkan Rasio Kepatuhan Pajak di Indonesia. Retrieved September 18, 2015, from http://www.pajak.go.id/content/ar ticle/meningkatkan-rasiokepatuhan-pajak-di-indonesia

Rosdiana, H., \& Irianto, E. S. (2014). Pengantar Ilmu Pajak Kebijakan dan Implementasi di Indonesia. Jakarta: PT Raja Grafindo Persada.

Saad, N. (2012). Tax Non-Compliance Behaviour: Taxpayers' View. Social and Behavioral Sciences, 65(ICIBSoS), 344-351. http: / / doi.org/ 10.1016/j.sbspro.20 12.11 .132

Saad, N. (2014). Tax Knowledge , Tax Complexity and Tax Compliance: Taxpayers' View. Procedia - Social and Behavioral Sciences, 109(1), 1069-1075.

http://doi.org/ 10.1016/j.sbspro.20 13.12 .590

Setiyaji, G. (2007). Ruwetnya Urusan Tax Ratio. Harian Sindo 4 September 2007.

http: / / doi.org/https: / / gsetiyaji.file s.wordpress.com/2007/09/ruwettax-ratio.pdf

Torgler, B. (2003). The Importance of Faith: Tax Morale and Religiosity. Center for Research in Economics, Management and the Arts (CREMA), 08, 1-35.

Torgler, B. (2012). Tax morale, Eastern Europe and European enlargement. Communist and Post-Communist Studies, 45(1-2), 11-25. http:/ /doi.org/10.1016/j.postcoms tud.2012.02.005

Torgler, B., Demir, I. C., Macintyre, A., \& Schaffner, M. (2008). Causes and Consequences of Tax Morale: An Empirical Investigation. Economic Analysis and Policy, 38(2), 313339. Retrieved from http:/ / qut.summon.serialssolution s.com

Van Dijke, M., \& Verboon, P. (2010). Trust in authorities as a boundary condition to procedural fairness effects on tax compliance. Journal of Economic Psychology, 31(1), 8091.

http://doi.org/ 10.1016/j.joep.2009 .10 .005

Wahyuni, M. A. (2011). Tax Evasion : Dampak dari Self Assessment System. Jurnal Ilmiah Akuntansi Dan Humanika, 12.

Weaver, G. R. (2002). Religiosity and Ethical Behavior in Organizations: A Symbolic Interactionist Perspective. Academy of Management, 27(1), 77-97. 